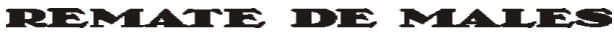

Campinas-SP, v. 38, n. 1, pp. 100-115, jan./jun. 2018

\title{
“SOMOS ÍNDICOS!”: NOTAS SOBRE A QUESTÃO IDENTITÁRIA EM TERRA SONÂMBULA, DE MIA Couto
}

\author{
Anita Martins Rodrigues de Moraes ${ }^{1}$
}

Resumo: No romance Terra sonâmbula (1992), de Mia Couto, o Oceano Índico surge como garantia e metáfora de experiências identitárias agregadoras, que se fazem pelo acolhimento do outro, e não por sua negação. A própria experiência literária surge como produtora de espaços propícios a esse tipo de exercício identitário, já que a terra se torna fluida e movente por meio das palavras de Kindzu, lidas por Muidinga. Neste trabalho, pretendo investigar a configuração dessa espécie de alternativa identitária em Terra sonâmbula, sugerindo que implica a problematização do discurso da modernidade e seus binarismos.

Palavras-chave: literatura moçambicana; modernidade e tradição; literatura e antropologia.

1.

A tese dequeo romance Terra sonâmbula (1992), de Mia Couto, articula tradição e modernidade é frequente noâmbito de sua fortuna crítica, como demonstra Kamila Krakowska (2014) em "Entre o passado tradicional e o futuro socialista: as modernidades moçambicanas em Terra sonâmbula, de Mia Couto". Pretendo, aqui, revisitar tal chave de leitura, investigando como certos índices das tradições africanas são configurados na obra. Devo, contudo, evitar, do mesmo modo que Krakowska, a atribuição de caráter substantivo a oposições como "tradição e modernidade", "oralidade

1 Professora de Teoria da Literatura na Universidade Federal Fluminense: anitademoraes@ gmail.com. 
e escrita", "África e Europa", entendendo que tais binarismos merecem, eles próprios, apreciação detida. Afinal, classificar algo como tradicional ou moderno pode implicar a adesão, mesmo que inconsciente, à ideia de que o Ocidente é, de alguma maneira, detentor do presente e do futuro. Em tal classificação, há atribuição de valor: o "tradicional" associa-se ao passado, ao "primitivo", ao "arcaico", àquele que habita regiões "remotas", "atrasadas", ou, quando o sinal positivo se inverte, "puras”, "ainda não corrompidas", "autênticas".

Mary Louise Pratt (1999, p. 44), em "Pós-colonialidade: projeto incompleto ou irrelevante?", propõe que "um dos principais conceitos que devem ser descolonizados é a própria modernidade”. A estudiosa acrescenta:

\begin{abstract}
A modernidade se define relativamente a uma gama total de "outros" feudalismo, absolutismo, o primitivo (ou seja, tribos indígenas e sociedade de subsistência), o tradicional (quer dizer, os camponeses e as sociedades rurais), os irracionais (animais, não-ocidentais e mulheres), os subdesenvolvidos ou atrasados (o mundo colonial/ neocolonial), o não-Ocidental. O que permanece invariável é que sempre deve haver um Outro. (PRATT, 1999, p. 45)
\end{abstract}

A necessidade de um "outro" para aquele que se diz "moderno", aponta para a "Grande Divisão" teorizada por Bruno Latour (1991) em Jamais fomos modernos. Em sua perspectiva, a modernidade ampara-se na crença de que a ciência moderna, tida como uma construção do Ocidente, produzira uma grande cisão entre esse mesmo Ocidente e o resto do mundo. Tal cisão supõe outra: a nítida distinção entre natureza e sociedade/cultura. Para Latour, os "outros" do discurso da modernidade seriam justamente aqueles considerados incapazes de ver a realidade tal qual, pois projetariam o que é próprio da sociedade e da cultura na natureza. A ideia de modernidade supõe, portanto, certa ideia de natureza, de sociedade e de cultura, ou seja, uma determinada configuração dos domínios do humano e do não humano; sugere, ainda, uma espécie de estágio mais avançado da racionalidade humana, uma fase adulta da humanidade, em que o homem seria capaz de se distinguir claramente daquilo que não é, ou seja, apartar-se do não humano ou da natureza. Outros modos de configurar, discernir e relacionar natureza e sociedade/ cultura são, então, associados a irracionalidade, ignorância e atraso. Práticas de magia e adivinhação, que supõem a participação e intervenção do humano no mundo natural, a possibilidade de comunicação entre tais 
domínios, são tomadas, pelos “modernos”, como sobrevivências infantis de uma fase superada pela modernidade.

Latour nos adverte de que a separação entre ciências naturais e ciências humanas alicerça-se na crença em tal "Grande Divisão" sociedade humana de um lado; realidade natural de outro. Para Pratt (1999, p. 45), no âmbito das próprias ciências humanas, a configuração disciplinar também se vê comprometida com o discurso da modernidade e seus "outros":

As fronteiras multifacetadas com esses outros têm sido policiadas e reproduzidas pelas modernas disciplinas acadêmicas institucionalizadas no centro na segunda metade do XIX. A antropologia produz e reforça a categoria do primitivo; a economia as de atraso e subdesenvolvimento. A ciência política administra as distinções entre estado e não-estado, sociedades simples e complexas; a filosofia distingue entre racional e irracional; os estudos literários e história da arte entre alta e baixa culturas. A história administra o conceito de tempo progressivo e determina quem o ocupa e quem não.

Tanto Latour como Pratt nos convidam a suspeitar do discurso da modernidade e a atentar para o modo como as próprias áreas do conhecimento se configuraram em seu caldo. Torna-se, assim, premente a disposição autorreflexiva, a atenção acurada para o uso que fazemos de certas categorias-chave em nossas disciplinas.

Como lembra Pratt (1999, p. 46), "pensadores baseados fora do Ocidente ou na zona de contato", têm operado "a descolonização do conhecimento iniciada na década de 1960 e acelerada nos anos 70 e 80", de modo que "a modernidade está atualmente sendo analisada sob uma perspectiva muito mais global que antes". O romance de Mia Couto se elabora justamente nesse contexto global de questionamento (o presente referido por Pratt são os anos 1990), desafiando seus leitores a suspeitar das referências que mobilizam, a revisitar criticamente aquilo que possam entender por "a realidade". Escritor na "zona de contato", Mia Couto elabora o que podemos chamar de narrativas-problema, lidando de modo complexo com o discurso da modernidade e seus "outros". Nesse sentido, partilha com autores como Valentin Y. Mudimbe e Kwame Anthony Appiah contundente empenho desconstrutor, torcendo em discurso perceptível certas ideias de África.

Mudimbe, ao longo de The Invention of Africa (1988) e The Idea of Africa (1994), percorre vasta gama de materiais, trazendo à tona traços da intricada cadeia discursiva responsável pela invenção de uma ideia de África. Em “The Power of the Greek Paradigm”, capítulo terceiro de The 
Idea of Africa, Mudimbe traça uma espécie de "geografia imaginativa” do mundo antigo, ${ }^{2}$ notando que, em Heródoto, Estrabão e Plínio, diferentes regiões e povos são caracterizados a partir de sua relação com o mundo grego ou romano. Segundo Mudimbe (1994, p. 92), o paradigma antigo foi reavivado no século XVIII: "Applied anthropology in this century has backed up Strabo's analysis, defining its project as a scientific reactivation of the Greek and Roman politics". ${ }^{3}$

The origins of cultural anthropology, as I've argued elsewhere, lie in the Western desire to discover its own past, and it constructed an imaginary trajectory that begins with the so-called primitive and culminates in the attainments of European civilization. (MUDIMBE, 1994, p. 186)

Para o autor, "the discovery of primitiveness was an ambiguous invention of a history incapable of facing its own double" (MUDIMBE, 1994, p. 190). ${ }^{5}$

Podemos notar certa convergência entre as proposições de Mudimbe, Pratt e Latour: problematizar o discurso da modernidade e suas disciplinas científicas, visibilizar uma história de construção do "outro" - o não europeu, o não moderno, o não ocidental... como espelhos invertidos do "próprio". Trata-se de trazer à tona um mecanismo de construção identitária marcado pela invenção de um par, de um "outro" que seja o próprio avesso (aquilo que se nega ou, paradoxalmente, o que se deseja ser ou recuperar). Penso que Mia Couto se mostra bastante atento a tal mecanismo. Em "A fronteira da cultura", texto que abre o volume Pensatempos (2005, p. 11), afirma:

2 A noção de "geografia imaginativa" elaborada por Said é, aqui, incontornável. Ler especialmente o capítulo "A geografia imaginativa e suas representações: orientalizando o oriental", de Orientalismo (SAID, 2007).

3 "A antropologia neste século corroborou a análise do Estrabão, definindo seu projeto como uma reativação científica da política grega e romana."

4 "As origens da antropologia cultural, como argumentei em outro momento, repousam no desejo do Ocidente de descobrir seu próprio passado, e isso construiu uma trajetória imaginária que teria se iniciado com os chamados primitivos e culminaria nas conquistas da civilização europeia."

5 "[...] a descoberta da condição primitiva foi uma ambígua invenção de uma história incapaz de encarar seu próprio duplo”. 
Uma grande parte da visão que temos do passado do nosso país e do nosso continente é ditada pelos mesmos pressupostos que ergueram a história colonial. Ou melhor, a história colonizada. O que se fez foi colocar um sinal positivo onde o sinal era negativo. Persiste a ideia de que a África pré-colonial era um universo intemporal, sem conflitos nem disputas, um paraíso feito só de harmonias. Essa imagem romântica do passado alimenta a ideia redutora e simplista de uma condição presente em que tudo seria bom e decorreria às mil maravilhas se não fosse a interferência exterior. Os únicos culpados dos nossos problemas devem ser procurados fora, nunca dentro. Os poucos de dentro que são maus é porque são agentes de fora.

$[\ldots]$

Numa conferência em que este ano participei na Europa, alguém me perguntou: o que é, para si, ser africano? E eu lhe perguntei, de volta: E para si, o que é ser europeu? Ele não sabia responder. Também ninguém sabe exatamente o que é africanidade. Neste domínio há muita bugiganga, muito folclore. Há alguns que dizem que o "tipicamente africano" é aquele ou aquilo que tem um peso espiritual maior. Ouvi dizer que nós, africanos, somos diferentes dos outros porque damos muito valor à nossa cultura. Um africanista numa conferência em Praga disse que o que media a africanidade era um conceito chamado "ubuntu". E que esse conceito diz que "eu sou nos outros". Ora todos estes pressupostos me parecem vagos e difusos, tudo isto porque se toma como substância o que é histórico. As definições apressadas da africanidade assentam numa base exótica, como se os africanos fossem particularmente diferentes dos outros, ou como se suas diferenças fossem o resultado de um dado de essência. África não pode ser reduzida a uma entidade simples, fácil de entender. (COUTO, 2005, p. 19)

Em seu empenho por visibilizar a historicidade de representações acerca da África e suas ciladas, Mia Couto nota o perigo de que representações exóticas sejam incorporadas pelos próprios africanos. Nesse sentido, ecoam questões também colocadas por Kwame Anthony Appiah (1997, p. 96), em Na casa de meu pai:

Os ingleses, que tudo sabiam sobre as nações, puderam estender uma compreensão similar a seu substituto, a "tribo", e isso pôde significar a invenção de tribos onde, a rigor, nenhuma existia antes. [...] Na verdade, como afirmei [...], a própria África (como algo mais que uma entidade geográfica) deve ser entendida, em última instância, como um subproduto do racialismo europeu; a ideia de pan-africanismo fundamentou-se na noção do africano, a qual, por sua vez, baseou-se, não numa autêntica comunhão cultural, mas, como vimos, no próprio conceito europeu de negro. [...] Dito de maneira simples, o curso do nacionalismo cultural na África tem consistido em tornar reais as identidades imaginárias a que a Europa nos submeteu.

Para Appiah, a própria ideia de uma identidade africana comprometese com o olhar europeu, particularmente com a categoria de raça, 
essencializante e imobilizadora. ${ }^{6} \mathrm{O}$ mesmo empenho de desconstrução caracteriza o texto "As vozes da foto", também reunido em Pensatempos. Nele, Mia Couto faz as seguintes considerações:

Publicações diversas e extensos relatórios são produzidos para responder a qualquer coisa que, afinal, é irrespondível: “O que é a África?”. A imagem do continente africano escapa em mil fragmentos. Quando se pensa ter entendido, acaba-se vacilando: a chamada "realidade africana" está viajando por múltiplas transições, ocultando-se em sucessivas máscaras. [...] Mas é exatamente nessa indefinição que pode estar uma das maiores riquezas do continente. Porque esta falta de retrato obriga à procura, a revolver conceitos, a interrogar dogmas. Os africanos estão nessa situação de fronteira: ao aceitarem a sua identidade como sendo múltipla, mestiça e dinâmica eles têm a possibilidade de se reinventarem e não se perderem em ilusórias viagens à "essência" de sua identidade. (COUTO, 2005, pp. 79-8o)

Mia Couto sugere que a África é espaço propício para uma experiência identitária aberta à multiplicidade, empenhada em revolver conceitos e dogmas. Em "Por um mundo escutador", último texto do mesmo volume, o escritor retoma o problema das identificações rígidas e viciadas:

Fomos empurrados para definir aquilo que se chamam "identidades". Deram-nos para isso um espelho viciado. Só parece refletir a "nossa" imagem porque o nosso olhar foi educado a identificarmo-nos de uma certa maneira. [...] Onde deveríamos ver dinâmicas vislumbramos essências, onde deveríamos descobrir processos apenas notamos imobilidade. (COUTO, 2005, p. 156)

Parece-me que já em Terra sonâmbula, romance de 1992, configura-se uma alternativa identitária: à experiência identitária rígida, marcada pela fixidez, contrapõe-se uma experiência identitária aberta e agregadora. Pretendo, aqui, investigar justamente essa alternativa identitária no romance, revisitando a tese da mescla entre tradição (supostamente

6 Stuart Hall (2003, p. 40) fala de uma África nas Américas, de maneira que um discurso acerca da identidade africana passa também por uma ideia de África construída na diáspora, tornando-se "o significante, a metáfora, para aquela dimensão de nossa sociedade e história [do Caribe] que foi maciçamente suprimida, sistematicamente desonrada e incessantemente negada e isso, apesar de tudo que ocorreu, permanece assim". Para o autor, essa África do Novo Mundo "não é nem a África daqueles territórios agora ignorados pelo cartógrafo pós-colonial, de onde os escravos eram sequestrados e transportados, nem a África de hoje, que é pelo menos quatro ou cinco 'continentes' embrulhados num só, suas formas de subsistência destruídas, seus povos estruturalmente ajustados a uma pobreza moderna devastadora. A 'África' que vai bem nesta parte do mundo é aquilo que a África se tornou no Novo Mundo, no turbilhão violento do sincretismo colonial, reforjada na fornalha do panelão colonial" (p. 39). 
africana) e modernidade (supostamente europeia) a partir dela, atentando, então, para possíveis torções e rearranjos. Trata-se, assim, de conceber o romance coutiano como discurso em relação com outros discursos, dentre os quais o discurso da modernidade e o da tradição, investigando como os rearticula e problematiza.

2.

Parto de associações produzidas no romance coutiano em torno do Oceano Índico, sugerindo que este se torna metáfora de uma experiência identitária particularmente valorizada. Já na primeira parte do romance, no primeiro dos cadernos de Kindzu, temos a seguinte passagem:

E ele me passava um pensamento: nós, os da costa, éramos habitantes não de um continente mas de um oceano. Eu e Surendra partilhávamos a mesma pátria: o Índico. E era como se naquele imenso mar se desenrolassem os fios da história, novelos antigos onde nossos sangues se haviam misturado. Eis a razão porque demorávamos na adoração do mar: estavam ali nossos comuns antepassados, flutuando sem fronteiras. Essa era a raiz de minha paixão de me encaseirar no estabelecimento de Surendra Valá.

- Somos de igual raça, Kindzu: somos índicos!

Ele se ria, repetindo: não indianos mas índicos. Eu fingia achar graça, rindo apenas de boa disposição. Enquanto ali estávamos, fazendo o absoluto nada, eu me sentia promovido. Na troca de nossos nenhuns assuntos, Surendra se esquecia de atender os fregueses. Eu me confortava: nunca ninguém se havia esquecido de nada por causa de mim. (COUTO, 1996, p. 29)

Para Kindzu, narrador-personagem de parte do romance, como sabemos, o estabelecimento comercial de Surendra Valá torna-se espaço de exercício e reconhecimento de uma identidade índica, resultante da mistura de sangues e histórias. ${ }^{7}$ Em sua perspectiva, adorar o mar seria contemplar "novelos antigos": "estavam ali nossos comuns antepassados, flutuando sem fronteiras". O valor de experiências identitárias feitas de mistura, sem fronteiras rigidamente marcadas, já de início se apresenta. Contudo, logo empecilhos se impõem. Vejamos:

7 Para um estudo de problemas implicados na representação da personagem indiana na literatura moçambicana, com atenção para a utilização do estereótipo e do exotismo, conferir trabalho de Nazir Can (2012). Segundo o estudioso, em Terra sonâmbula, Mia Couto inventa "a personagem indiana exemplar, que inspira os caminhos identitários escolhidos pelo herói (e pela nação)” (p. 221). 
Uma noite os bandidos atacaram a loja do indiano, roubaram os panos, queimaram o edifício. A notícia correu rápido. Ninguém dispensou nenhum sentimento pela desgraça de Valá. Ele era um de fora, nem merecia as penas.

$[\ldots]$

- Tu tens antepassados, Kindzu. Estão aqui, moram contigo. Eu não tenho, não sei quem foram, não sei onde estão. Vês, agora, o que aconteceu? Quem é que me veio consolar? Só tu, mais ninguém.

Eu não queria entender o lojeiro. Porque suas palavras matavam a miragem de um oceano que nos unira no passado. Afinal, Surendra estava sozinho, sem laço com vizinhas gentes, sem raiz na terra. Não tinha ninguém de quem despedir. Só eu. Ainda insisti, subitamente pequenito, entregando ideias que meu peito não autenticava. Que aquela terra também era a dele, que todos cabiam nela. Só no falar senti o sabor salgado da água dos olhos: eu chorava, o medo me afogava a voz.

- Que pátria, Kindzu? Eu não tenho lugar nenhum. Ter pátria é assim como você está fazer agora, saber que vale a pena chorar.

Antoninho, o ajudante, escutava com absurdez. Para ele eu era um traidor da raça, negro fugido das tradições africanas. Passou por entre nós dois, desdelicado provocador, só para mostrar seus desdéns. No passeio, gargalhou-se alto e mau som. Me vieram à lembrança as hienas. Surendra disse, então:

- Não gosto de pretos, Kindzu.

- Como? Então gosta de quem? Dos brancos?

- Também não.

- Já sei: gosta de indianos, gosta da sua raça.

- Não. Eu gosto de homens que não têm raça. É por isso que eu gosto de si, Kindzu. (COUTO, 1996, pp. 32-33)

Podemos notar que as experiências identitárias associadas ao Oceano Índico se distinguem daquelas que se valem da ideia de raça para categorizar e, consequentemente, apartar as pessoas. Ter raça (ser indiano, branco, negro) e ser índico apresentam-se, então, como duas distintas formas de construção identitária, com desdobramentos diversos. Ser índico é dispor-se ao encontro, construir relações de solidariedade e amizade com pessoas de origens diversas a partir do reconhecimento de uma ancestralidade humana comum; ter raça, ao contrário, associa-se à hostilidade, à recusa e negação do outro. ${ }^{8}$

A experiência identitária agregadora associada ao Oceano Índico surge, já de início, ameaçada. Torna-se uma espécie de aposta que atravessa todo o romance e será articulada - esta é minha sugestão - à própria experiência de leitura dos cadernos de Kindzu. De outra maneira: a leitura em voz alta dos cadernos instaura um espaço não previsto no

8 Para um estudo dos imaginários associados ao Oceano Índico, tanto coloniais como de pós-independência, e tendo em conta o interesse de investigar alternativos discursos identitários que se articulam a partir desse mar, ler Brugioni (2015). 
presente impeditivo da guerra, um espaço de imaginação, encontro e partilha. Há efeitos mágicos decorrentes da leitura em voz alta: a paisagem se transforma, a terra se move fazendo com que Muidinga e Tuahir viajem em direção ao mar. ${ }^{9}$ A experiência de leitura/escuta - o brincar de ser para além de si - parece relacionar-se à experiência identitária agregadora, índica, pois permite o ultrapassamento do que se apresenta como realidade dada, permitindo e possibilitando novas realidades. De certa maneira, o espaço de encontro entre Kindzu e Surendra se repõe na leitura dos cadernos, é multiplicado pelos cadernos. Se a raça parece afirmar a identidade como fixa, configurando uma espécie de confinamento (assumindo ter certa raça, sou conduzido a ser sempre o mesmo, a desempenhar o mesmo papel), a fabulação parece permitir trânsitos, deslocamentos, pontes, produzindo abertura e propiciando espaços de ser para além do previsível, do previamente estabelecido, acolhendo-se a diferença. O romance parece, como tenho dito, contrapor experiências identitárias impeditivas, confinadoras, fixas e segregadoras a experiências identitárias propícias, abertas, fluidas e agregadoras. Por uma série de fatores, estas últimas se veem ameaçadas; como locus de encontro e jogo, a palavra literária (escrita e oral) associa-se à identidade índica, tornandose recurso de resistência e luta contra as forças do confinamento/fixidez/ impedimento/isolamento.

No quarto caderno de Kindzu, intitulado "Filha do Céu", temos uma série de afirmações acerca de ações que "a tradição ordena" (COUTO, 1996, p. 86). Kindzu, narrador-personagem, explica:

Farida era filha do Céu, estava condenada a não poder nunca olhar o arco-íris. Não lhe apresentaram à lua como fazem com todos os nascidos da sua terra. Cumpria um castigo ditado pelos milênios: era filha-gêmea, tinha nascido de uma morte. Na crença da sua gente, nascimento de gêmeos é sinal de grande desgraça. No dia seguinte a ela ter nascido, foi declarado chimussi: a todos estava interdito lavrar o chão. Caso uma enxada, nesse tempo, ferisse a terra, as chuvas deixariam de cair para sempre.

Dias depois, sua irmã morreu. Deixaram-na morrer com fome. Fizeram isso por bondade: para aliviar a maldição. Enterraram a menina no pequeno bosque sagrado onde dormem as crianças falecidas. Meteram-lhe numa panela de barro quebrada. Foi semeada sem quase nenhuma terra lhe cobrir. Destinaram-lhe

\footnotetext{
9 Para um estudo da atribuição de poderes à palavra em Terra sonâmbula - atentando para problemas teóricos implicados nessa chave de leitura -, conferir $O$ inconsciente teórico: investigando estratégias interpretativas de Terra sonâmbula, de Mia Couto (MORAES, 2009).
} 
um lugar perto do rio, onde o chão nunca seca. Assim as nuvens lembrar-se-iam sempre da obrigação de molhar a terra. (COUTO, 1996, pp. 85-86)

Sabemos que Mia Couto é leitor dos trabalhos do missionário suíço Henri Junod, sobre quem escreveu um apontamento biográfico que integra o volume E se Obama fosse africano? e Outras interinvenções (2009). ${ }^{10}$ No capítulo “O Céu, os gêmeos e a chuva”, de Usos e costumes dos bantu (cuja primeira versão foi publicada por Junod em 1911), temos talvez o material de que partira Mia Couto para construir a história de Farida. Vejamos a seguinte passagem de Junod:

\begin{abstract}
Esta potência que causa o relâmpago e a morte está ligada, também, de maneira muito especial ao nascimento de gêmeos, de modo que a mãe deles é chamada, ela própria, Tilo, o Céu, e as crianças Vana va Tilo, filhos do Céu. Ora, a chegada a este mundo de dois ou três recém-nascidos ao mesmo tempo é considerada pelos Tsongas como uma grande desgraça, uma poluição por cuja causa se devem realizar ritos muito particulares. [...] Os gêmeos (hahla ou vandrwa) já não são, hoje, mortos. Deixam-nos viver ambos. Nos tempos antigos, porém, desembaraçavam-se daquele que fosse, aparentemente, mais fraco, deixando-o morrer de fome ou estrangulando-o com uma corda. (COUTO, 1996, p. 371)
\end{abstract}

Junod segue descrevendo os rituais de purificação da mãe de gêmeos, os mesmos que encontramos descritos no romance (por vezes, a impressão é de que o escritor quase parafraseia o missionário). Uma afirmação de Junod, contudo, chama a atenção: "os gêmeos já não são, hoje, mortos”. Surpreende essa diferença, em meio a tantas semelhanças entre o relato de Junod e o episódio construído por Mia Couto. " É digno de destaque, nesse sentido, que em Terra sonâmbula as chamadas tradições africanas surjam

10 Ana Mafalda Leite (2012, pp. 169-172) aponta o intertexto de Terra sonâmbula com a etnografia de Junod. Em seu estudo, sugere que esse romance é construído a partir de dois gêneros de origem oral: "o conto, enquanto macroestrutura, e o provérbio, enquanto microestrutura” (p. 170). A estudiosa destaca que "parte significativa do material temático fabuloso de Terra sonâmbula se fundamenta nas tradições dos povos do sul de Moçambique, estruturando-se também, o romance, enquanto gênero, na intertextualização do gênero oral de entretenimento ritual diário, o conto ou variantes similares" (p. 172). Em sua análise, aponta como o romance adquire complexidade, numa estrutura de encaixe e espelhamentos internos (p. 173). Investiga, ainda, o problema da recepção, considerando diferentes receptores, o indígena e o alienígena (pp. 182-185).

11 Não se trata, aqui, de recorrer a uma etnografia para sugerir algum engano na representação de certo costume apresentado como tradicional por Mia Couto. Afinal, além do fato de que o autor possa ter outras referências complementares à descrição junodiana, o que me parece importante é notar como elementos que apontam para as culturas bantu são ficcionalizados, ou seja, de quais sentidos se imbuem na armação romanesca, não sua faticidade. 
repetidamente associadas a impedimento, violência e morte. Temos, talvez, a representação no romance de forças impeditivas e restritivas, com desdobramentos violentos e mesmo mortais, antecedendo o colonialismo e a guerra presente. A devastação, o horror da guerra e a brutalidade das relações coloniais (brutalidade que tem no estupro de Farida por Romão Pinto seu momento mais terrível) deverão coabitar, no romance, com prévias disposições impeditivas e violentas. De outra maneira: Farida, vítima de Romão Pinto, fora já vítima de sua própria sociedade (fora marginalizada, considerada impura e feita órfã). Os ataques que sofre são, assim, múltiplos.

Noto, então, que as tradições serão, por vezes, associadas a impedimento e violência: temos o mampfana, ave que mata as viagens (COUTO, 1996, pp. 25 e 228);:' temos o ritual das senhoras idosas que, surpreendidas por Muidinga, agridem-no (pp. 122-123);13 temos as repetidas maldições de Taímo, pai de Kindzu, quando já morto; temos o racismo de Antoninho, recorrendo ao discurso da fidelidade às tradições africanas (p. 33). Contudo, penso que essa negatividade associada ao que seria a tradição é bastante ambígua, pois o que se apresenta como impedimento pode ser outra disposição, apenas assim disfarçada (este é o caso, parece-me, da relação de Taímo, morto com seu filho Kindzu, por exemplo); além disso, ao final do romance, será um feiticeiro, associado às tradições, que anunciará um novo tempo, em que a "memória de sermos gente" garantirá relações estabelecidas nos termos da identidade índica. Penso, assim, que o romance tende a produzir associações tanto de restrição, confinamento, impedimento e violência com relação ao universo apresentado como tradicional, como associações de renascimento, movimento e revitalização. O episódio de Siqueleto é, então, emblemático: à captura e aprisionamento de Muidinga e Tuahir, sucede a palavra grafada investida de força vital e a metamorfose de Siqueleto em semente (pp. 7784). ${ }^{14}$ Certamente, a história das irmãs Farida e Carolinda responde pela força da associação negativa. Contudo, se duas experiências identitárias se contrapõem no romance, a identidade índica (associada a abertura, possibilidade, movência, agregação) e a identidade rácica (associada a fechamento, impedimento, fixidez e segregação), os modos tradicionais

\footnotetext{
12 Conferir Henri Junod (1996, pp. 289-290).

13 Conferir apontamentos de Ana Mafalda Leite (2012, p. 172) e Henri Junod (1996, pp. 268 e 377).

14 Sobre tal episódio, conferir leitura de Ana Mafalda Leite (2012, pp. 177-178).
} 
surgem associados a ambas, não se localizando exclusivamente em uma ou outra configuração identitária.

Talvez possamos, partindo da alternativa identidade índica/ identidade rácica, aproximar episódios por um traço comum: a negação de condições de existência àqueles que se veem marcados por algum traço de diferença - por exemplo, a condição de minoria (o caso de Surendra, indiano); a mestiçagem (Gaspar, que não seria acolhido na aldeia de Farida por ser mulato); a gemelaridade (no caso das irmãs gêmeas Farida e Carolinda - a primeira, crescendo marginalizada em sua aldeia; a segunda, destinada ao sacrifício, sendo secretamente doada pela mãe para que pudesse sobreviver). Há uma força impeditiva nos três casos que se mostra prévia à guerra vigente, agente máximo de impedimento e destruição.

O período do colonialismo português surge no romance com alguns traços positivos: a escola, a missão, a figura maternal de Virgínia, os comboios de Tuahir. Vejamos melhor como se apresenta a nostalgia de Tuahir de quando era empregado ferroviário no período colonial:

O velho se lembrava, olhos quiméricos. Recordava o trem resfolegando pela savana, trazendo as boas simpatias de muito longe, os mineiros que chegavam carregados de mil ofertas. Sua memória se inundava de vapores e fumos, esses que cacimbam as sonolentas estações. Há quanto tempo os comboios tinham parado de espalhar seus fumos mágicos? (COUTO, 1996, p. 165)

A representação dos mineiros em trânsito é positiva e alegre - no período colonial, ao contrário do presente contaminado pela guerra, havia a possibilidade da viagem, das trocas. O elemento brutal do colonialismo se associa à figura de Romão Pinto, como disse já. No conjunto, porém, a presença portuguesa resulta ambígua, tendendo mesmo a se associar às experiências identitárias índicas - de abertura à diferença e à mistura. Lembremos que é a aldeia de Farida que tem dificuldade em acolher o menino Gaspar, por ser mestiço, da mesma maneira que não integrou Farida e Carolinda por serem gêmeas (Virgínia e as freiras da missão, ao contrário, acolhem tanto Gaspar como sua mãe, Farida); é a guerra presente que surge como força arrasadora, causadora de miséria e morte. É essa guerra dos bandos armados que destrói a família de Kindzu ("como um pote lançado ao chão” - 1996, p. 19), que cala Taímo, antes contador de estórias. É entre a vida regida pelos códigos tradicionais e a vida impedida pela guerra e a corrupção do governo nacional, que encontramos, no romance, algumas das experiências propícias para a construção de 
identidades em mistura, ou índicas. Ou seja, se há o português Romão Pinto, há Virgínia como elemento compensador, positivo.

O romance Terra sonâmbula parece sugerir, assim, aspectos positivos e negativos no âmbito da presença colonial portuguesa. Em meio à guerra e aos descaminhos e à violência do governo nacional, ${ }^{15}$ serão, porém, ressuscitadas justamente as forças negativas do colonialismo português: Estevão Jonas - administrador e marido de Carolinda - associa-se ao morto Romão Pinto - figura da brutalidade colonial portuguesa - em negócios escusos (COUTO, 1996, pp. 202-205). Kindzu, por outro lado, acolhe e potencializa os aspectos positivos da presença portuguesa e indiana, deixando como legado sua estória - que inclui outras, como a de Farida e Carolinda. Como disse já, será por meio dos cadernos por ele escritos que Tuahir e Muidinga encontrarão um espaço de resistência, construindo condições de superação diante de forças impeditivas e mesmo mortais. É por meio deles - de sua leitura - que Muidinga virá a se tornar Gaspar, reconstruindo sua identidade pelo exercício do imaginar. $\mathrm{O}$ ato de contar histórias, traço comum a Taímo (africano) e Virgínia (portuguesa), ressurge em Kindzu pela escrita e em Muidinga pela leitura em voz alta (incluindo, assim, Tuahir). A experiência literária/imaginativa parece garantir e propiciar a experiência identitária índica. De certa maneira, o modo de vida que se configura como tradicional e o que remete à presença portuguesa surgem com aspectos positivos e negativos no romance, sendo tarefa do presente, inclusive da literatura (figurada nos cadernos de Kindzu), lidar com seus legados de maneira a construir e potencializar aspectos convergentes com a identidade índica e combater aqueles que corroboram uma identidade rácica.

Talvez possamos pensarque o discurso da modernidade, na construção de seus "outros", funcione à maneira da identidade rácica, como delineada

15 Para um estudo da representação do discurso do governo nacional no romance, conferir Krakowska (2014). A estudiosa propõe que o romance ironiza o discurso da modernidade elaborado pela Frelimo (Frente de Libertação de Moçambique), que a autora considera subordinado ao modelo soviético (KRAKOWSKA, 2014, p. 7). Matusse (1993), por sua vez, considera que a ficção de Mia Couto e a de Ungulani Ba Ka Khosa estão implicadas na construção de uma imagem de moçambicanidade em tensão com o discurso de nação da Frelimo e sua violenta desqualificação das culturas tradicionais africanas. Para uma discussão mais detida acerca do projeto e do governo da Frelimo, ler Cabaço (2009, pp. 243-325). Sobre a política cultural do pós-independência, ler Borges (2001). 
no romance coutiano. Seu suposto avesso, o discurso da tradição, incorreria no mesmo mecanismo de recusa do "outro", apenas invertendo-se o sinal (o mal estaria do lado do supostamente moderno). Importa, contudo, notar que, no âmbito do discurso da modernidade, o tradicional costuma ser associado à imutabilidade, inflexibilidade e repetição; o moderno seria, então, o modo aberto à transformação, à renovação. Além disso, o africano seria associado ao tradicional, de maneira que qualquer mudança seria esperada como consequência da interferência do modo de vida ocidental. Penso que Mia Couto empenha-se justamente em questionar tais associações: movimento e transformação surgem na ação de personagens como a mãe de Farida e Carolinda, que se recusa a seguir o que "a tradição ordena" (COUTO, 1996, p. 86); a defesa de uma identidade aberta e relacional surge como lição de Surendra Valá, um indiano; tal lição será aprendida por Kindzu e será a sua palavra, na voz de Muidinga que lê seus cadernos a Tuahir, uma palavra capaz de mover a própria terra; é, ainda, o canto de Kindzu que, em sonho, recupera a forma humana de Junhito, personagem-alegoria da Independência de Moçambique. ${ }^{16}$

Tal força atribuída à palavra remete à magia, particularmente à "magia verbal”, nos termos de Junod (1996, p. 358); remete à comunicação com a natureza e os ancestrais (para Junod [p. 359], antepassados-deuses); e remete também ao sonho, compreendido justamente como lugar de encontro e comunicação entre vivos e mortos, ainda segundo Junod (p. 329). Em Terra sonâmbula, os elementos constitutivos da própria narrativa - tempo, espaço, enredo e foco narrativo - são configurados a partir do sonho-comunicação e da palavra-força (ao final do romance, os elementos da narrativa se dissolvem, sugerindo-se o desfazimento, em terra, do próprio livro que temos em mãos). De outra maneira: não há moldura que contenha tais atribuições de comunicação e força ao sonho e à palavra, respectivamente; são, ao contrário, tais atribuições que configuram o próprio romance e seu mundo movente. Em Terra sonâmbula, o leitor não é dotado de um ponto de vista sobreposto que lhe permita circunscrever uma "cosmovisão africana" (no caso, de sociedades bantu moçambicanas), afinal, não há, na estrutura narrativa, um olhar de fora que a encerre.

16 Vale a pena reler Said (2011, p. 101): "Os discursos universalizantes da Europa e dos Estados Unidos modernos, sem nenhuma exceção significativa, pressupõem o silêncio, voluntário ou não, do mundo não europeu. Há incorporação; há inclusão; há domínio direto; há coerção. Mas muito raramente admite-se que o povo colonizado dever ser ouvido e suas ideias, conhecidas". 
Trata-se, parece-me, de uma radical tomada de posição: o romance não dá a conhecer certa cosmovisão africana, mas sim concebe o mundo ficcional a partir de suas balizas, certamente também ficcionalizadas.

Parece-me que o discurso da modernidade (supostamente europeia) e da tradição (supostamente africana) se desmonta no romance. Aliás, a metáfora do Oceano Índico, sugestiva de uma propícia experiência identitária, aponta para um espaço de trânsitos, trocas e encontros que antecede e ultrapassa a presença europeia. Assim, o europeu é apenas mais uma presença, entre outras tantas, em interação nesse Oceano. Se à modernidade costuma-se atribuir o monopólio da transformação e do futuro, o romance coutiano parece, com tal deslocamento, afirmar uma possibilidade índica, em que a África e o Oriente sejam protagonistas. Não se trata, portanto, de produzir sínteses entre África e Europa, mas de produzir radicais deslocamentos e torções.

\section{“SOMOS ÍNDICOS!": NOTES ON THE IDENTITY ISSUE IN TERRA SONÂMBULA, BY MIA COUTO}

Abstract: In Mia Couto's novel Terra sonâmbula (1992), the Indian Ocean emerges as a guarantee and metaphor for aggregating identity experiences, which are made by welcoming the other and not by their denial. The literary experience itself arises as the producer of spaces conducive to this type of exercise of identity, since the earth becomes fluid and moving through the words of Kindzu read by Muidinga. In this work, I intend to investigate the configuration of this kind of identity alternative in Terra sonâmbula, suggesting that it implies in the problematization of the discourse of modernity and its binarisms.

Keywords: mozambican literature; modernity and tradition; literature and anthropology.

\section{REFERÊNCIAS}

APPIAH, Kwame Anthony. Na casa de meu pai. Rio de Janeiro: Contraponto, 1997.

BORGES, Edson. A política cultural em Moçambique após a Independência. In: FRY, Peter (Org.). Moçambique: ensaios. Rio de Janeiro: Editora UFRJ, 2001, pp. 224-247.

BRUGIONI, Elena. Por detrás de tantos nomes, o mar. Moçambique e o Oceano Índico: discursos, imaginários e representações. Revista Via Atlântica, São Paulo, n. 27, jun. 2015, pp. 93-110.

CABAÇO, José Luís. Moçambique: identidade, colonialismo e libertação. São Paulo: Editora da Unesp, 2009. 
CAN, Nazir. Os lugares do indiano na Literatura Moçambicana. In: CHAVES, Rita; MACEDO, Tania. Passagens para o Índico: encontros brasileiros com a literatura moçambicana. Maputo: Marimbique, 2012, pp. 217-230.

COUTO, Mia. Terra sonâmbula. Rio de Janeiro: Nova Fronteira, 1996.

COUTO, Mia. Pensatempos: textos de opinião. Lisboa: Caminho, 2005.

COUTO, Mia. E se Obama fosse africano? e Outras interinvenções. Lisboa: Caminho, 2009.

HALL, Stuart. Da diáspora: identidades e mediações culturais. Belo Horizonte/Brasília: Unesco/ UFMG, 2003.

JUNOD, Henri. Usos e costumes dos bantu (tomo II). Maputo: Arquivo Histórico de Moçambique, 1996.

KRAKOWSKA, Kamila. Entre o passado tradicional e o futuro socialista: as modernidades moçambicanas em Terra sonâmbula, de Mia Couto. Configurações [on-line], dez. 2013. Disponível em: <http://configuracoes.revues.org/2099>. Data de acesso: 1 out. 2016.

LATOUR, Bruno. Jamais fomos modernos. Rio de Janeiro: Editora 34, 1994.

LEITE, Ana Mafalda. Oralidades e escritas pós-coloniais. Rio de Janeiro: EdUERJ, 2012.

MATUSSE, Gilberto. A construção da imagem de moçambicanidade em José Craveirinha, Mia Couto e Ungulani ba ka Khosa. Dissertação (Mestrado em Literatura Comparada) - Universidade Nova de Lisboa. Lisboa, 1993.

MORAES, Anita Martins Rodrigues de. O inconsciente teórico: investigando estratégias interpretativas de Terra Sonâmbula, de Mia Couto. São Paulo: Annablume/Fapesp, 2009.

MUDIMBE, V. Y. The invention of Africa. Bloomington/Indianápolis: Indiana University Press, 1988.

MUDIMBE, V. Y. The idea of Africa. Bloomington/Indianápolis: Indiana University Press, 1994 .

PRATT, Mary Louise. Pós-colonialidade: projeto incompleto ou irrelevante? In: VÉSCIO, Luiz Eugênio; SANTOS, Pedro Brum (Orgs.). Literatura e história: perspectivas e convergências. Bauru: Edusc, 1999, pp. 17-54.

SAID, Edward W. Orientalismo. São Paulo: Companhia das Letras, 2007.

SAID, Edward W.. Cultura e imperialismo. São Paulo: Companhia das Letras, 2011. 